\title{
THE IMPACT OF THE NAMES OF DISHES ON THE GUEST'S CHOICE OF RESTAURANT FOOD
}

\author{
Dragan Tešanović, \\ Maja Banjac, \\ Bojana Kalenjuk, \\ Goran Radivojević
}

University of Novi Sad,

Faculty of Sciences,

Department of Geography, Tourism and Hotel Management,

Novi Sad, Serbia

\begin{abstract}
:
Menus represent the written food offer in restaurants. They are a significant marketing tool that influences the guest's choice and personal experience of food in the restaurant. The aim of this study is to perform research on the specific segments of the menu that affect the guest's decision on food choice. The study will try to determine how the names of dishes that are associated with health, sentimentality and ethnic origin have an effect on the guest's choice of food. It is considered that the menus that associate with the given names are to appeal to guests even though they are similar to classic dishes. The research has been conducted in a la carte restaurants. Five menus, offering the dishes made of the same ingredients but with different names, have been offered for the research needs. The "classic" name has been given to the specific dish and the same dish has been titled with "sentimental" name, "authentic" name, "national" name, "organic" or "healthy safe" name and the name that associates with "memory of a family". The participants have marked the menu using the Likert scale (the most appealing 5 to the least appealing 1) without knowing that they have been grading the same dish. The data has been systematized and processed by means of descriptive statistics. The research results will show that the names of dishes have significant effects on the guest's choice of food. The results should make the managers of the restaurants pay more attention to the names of dishes during the process of menu creation. Also, these findings should contribute to the improvement of the restaurants' service.
\end{abstract}

Keywords:

menu, restaurants food, hospitality, names of dishes.

\section{LITERATURE REVIEW}

The attractive descriptive names of restaurant dishes directly influence the consciousness and the guest's personal experience before and after the consumption of the dishes (Carddelo, 1986; Vansink \& Park 2002; Wansink, 2003). On the basis of what have been said, it could be noticed that the names of dishes besides their similar sensory characteristics more appeal to the guest than the dishes with classic names. This statement could be confirmed by the finding that when the products made of offal had been launched to the American market and had not been given true names, the demand for such products had largely increased until the true nature of this product was not discovered (Wansink \& Park, 2002). 
In order to realize the plans of restaurant business, it is important to create convenient menus for target group of guests (Tešanović, 2012). The creators of menus need to have knowledge of all elements important for making the appealing and stimulating offer (Lončar \& Lončar, 2004; Tešanović, 2011 p. 54; Ozdemir \& Caliskan, 2014; Gagić, 2014; Kalenjuk et al., 2016). The significant segment of planning is to monitor the theme of the production and service of the restaurant (Morrison, 1996; Jones \& Mifli, 2001). It is believed that the names of dishes have direct impact on both the guest's personal experience and choice of food in the restaurant. The dishes that have descriptive names associated with family, nation, healthy and safe food and something authentic have more positive effects on the guest's choice of food than the dishes that have classical names. Creative and descriptive names of dishes increase the demand for these dishes (Wansink et al., 2001). Moreover, numerous studies confirm that the most attractive dishes regardless of their place in the menu are more likely to be ordered (Lorenzini, 1992; Tešanović, 2011).

Wansink et al. (2001) have conducted the study by replacing the dishes that have classical names with the same dishes giving them descriptive names. The survey data show that the sales of dishes rose by $27 \%$ in relation to the period when the dishes on offer had classic names.

The study conducted in schools in New York in 2001 shows that the name of a dish affected the choice. The carrot that had the descriptive name had been twice as much consumed compared to its offer with classical name (Wansink et al., 2012). The dishes with descriptive names have a hedonistic aspect and the name of the dish implies what might be expected from its taste (Wansink et al., 2004).

It is believed that the guests' provoked sentimental feelings influence their perception of high quality dish. The studies conducted in France show that the participants considered the food that had been consumed fifty years ago far better compared to the food consumed nowadays (Mermet, 2010, p. 46). Moreover, a significant number of participants considers the traditional food to be of more nutritional value and the meals to be more nutritionally balanced compared to the meals we consume today (Sheehy et al., 2016). Also, there is the belief that food made of local ingredients is more appealing, and thus its labeling in the menu can boost sale (O’Kane, 2016).

In the exclusive restaurants, one of the most crucial business strategies is innovative offer in the menus (Lane, 2013). It is believed that innovative approach has considerable influence on the consumers' perception of consumption that in return can directly affect future intentions. Also, the innovation means careful selection of the names of dishes.

The topic of the study is the restaurant's food created in menus with different names of emotional nature. The composition of dishes in all the menus is the same but the names of dishes in each menu differ. One of the menus has dishes with classical names and the rest of them have the names that associate with family, authenticity, nation and healthy and safe food.

The task of the study is to determine whether the names of dishes impact the consumers. Also, the aim of the study is to explore the extent to which the names of dishes in the menu affect the consciousness of the customer deciding on the choice of food.

\section{RESEARCH METHODOLOGY}

\section{The place of the research}

The research was conducted during the period from January 01 to February 01, 2016 in Novi Sad. The restaurant of a la carte type has been chosen for the purpose of this research. It disposes of sixty-four table seats while the capacity utilization is $76 \%$ on a monthly basis.

\section{The participants}

One hundred and forty six guests were randomly selected. During the research realization, the participants were not given any information, apart from the task to choose the most acceptable menu.

\section{The menus}

Five expanded menus have been composed for the purpose of the research and are presented in Table 1. One of the menus has dishes with classic names and the names of dishes in other four menus are associated with sentimentality, something authentic, nation, organic and healthy and safe food.

The participants graded each of the menus using the Likert numerical and descriptive scale (1 to 5). The participants have marked the most appealing menu with mark 5, mark 4 for the menu of average appeal, mark 3 for the menu that is neither appealing nor unappealing, mark 2 for the menu that is partially appealing, and mark 1 for the least appealing menu. 
Table 1.

\begin{tabular}{lllll}
\hline $\begin{array}{l}\text { 1. Restaurant's } \\
\text { "classical" menu }\end{array}$ & 2. Sentimental menu & 3. Authentic menu & 4. National menu & $\begin{array}{l}\text { 5. Organic/healthy } \\
\text { safe menu }\end{array}$ \\
\hline Chicken soup & $\begin{array}{l}\text { Grandmother's } \\
\text { yellow chicken soup }\end{array}$ & Clear chicken soup & $\begin{array}{l}\text { Soup made of } \\
\text { Vojvodina's farm } \\
\text { chicken }\end{array}$ & $\begin{array}{l}\text { Soup made of free } \\
\text { range chicken }\end{array}$ \\
\hline $\begin{array}{l}\text { Serbian traditional } \\
\text { roasted pork }\end{array}$ & $\begin{array}{l}\text { Grandpa's } \\
\text { traditional roasted } \\
\text { pork }\end{array}$ & $\begin{array}{l}\text { The authentic } \\
\text { traditional roasted } \\
\text { pork }\end{array}$ & Serbian roasted pork & $\begin{array}{l}\text { Traditional roasted } \\
\text { mangalitsa }\end{array}$ \\
\hline Mixed salad & Sister's mixed salad & Classic mixed salad & $\begin{array}{l}\text { Sumadija's country } \\
\text { salad }\end{array}$ & Organic mixed salad \\
\hline & $\begin{array}{l}\text { Aunt Nena's poppy } \\
\text { strudel }\end{array}$ & $\begin{array}{l}\text { Traditional poppy } \\
\text { strudel }\end{array}$ & $\begin{array}{l}\text { Banat's poppy } \\
\text { strudel }\end{array}$ & $\begin{array}{l}\text { Strudel filled with } \\
\text { organic poppy seeds }\end{array}$ \\
\hline
\end{tabular}

\section{Statistical analyses of data}

The marks of all participants are grouped and the results are analyzed by means of descriptive statistics: minimum ( $\min$ ), maximum ( $\max$ ), the coefficient of variation $(\mathrm{CV})$, a measure of standard deviation $(\sigma)$ and average value $(\bar{x})$.

\section{RESEARCH RESULTS AND DISSCUSION}

\section{Socio-demographic characteristics of the participants}

There have been one hundred and forty seven participants with an average age of 36.6 years. Accordingly, $60.7 \%$ of participants were women and 39.3 men. $32.5 \%$ of participants have a high school degree, $20.5 \%$ of them have a college degree, $41 \%$ have a bachelor's degree and $6 \%$ have a master's degree.

For the purpose of this research and convenience of the participants, an important question has been delivered: "How often do you visit restaurants?" $10.8 \%$ of the participants have answered once a week, $42.2 \%$ once a month and $47 \%$ several times a year.

Also, important information has been: "How long do you stay in the restaurant?" Namely, 15.7\% of respondents said that they stay approximately one hour, $74 \%$ answered one to two hours, and $9.6 \%$ said that they stay more than two hours.

\section{The analysis of menu selection}

During the research, the participants express their opinions on the most and least appealing menu. For the detailed analysis of data, the average value has been used as the most reliable statistical element. Table 2 shows the obtained data evaluation of all five menus.

Table 2 .

\begin{tabular}{lccccc}
\hline MENU & MIN & MAX & $\bar{x}$ & $\sigma$ & CV \\
\hline Classical & 1 & 5 & 2.00 & 1.18 & 1.39 \\
\hline Sentimental & 1 & 5 & 3.58 & 1.18 & 1.39 \\
\hline Authentic & 1 & 5 & 3.29 & 1.23 & 1.52 \\
\hline National & 1 & 5 & 3.23 & 1.09 & 1.20 \\
\hline $\begin{array}{l}\text { Organic/ } \\
\text { healthy safe }\end{array}$ & 1 & 5 & 3.62 & 1.69 & 1.37 \\
\hline
\end{tabular}

Table 2 shows the average value of graded menus. The largest number of guests (26\%) has chosen the first menu as the most appealing with the organic/healthy safe label with the average mark 3.62. It is believed that the offered menu has been marked with the highest average value because the consumption of such food has become the growing trend all around the world (Baourakis, 2004) and there is growing concern of consumers for their health as well. The participants consider the ecological food as something that is good, appealing and tasty (Lessa et al., 2013), which leads to a more positive experience (Wansink et al., 2004). Also, it should take into consideration that simple prepared small meals have been consumed these days (Roseboro, 2016). Gaste et al. (2015) confirm that various statements of nutrition have contributed to these results as well as the one that claims that consumption of fruits and vegetables provides the prevention against cancer (Ledikwe et al., 2005). Since the guests have been provided with alternatives when 
selecting the menu, the effect of attractive food can be observed herein (Dojl et al., 1999).

The average value of 3.58 of sentimental menu categorize it as the average appealing menu. $24 \%$ of participants have claimed this. The authentic menu is marked with 3.29 and it is described as neither appealing nor unappealing by $23 \%$ of participants. The national menu that is marked with 3.23 is partially appealing and it has been noticed by $16 \%$ of participants. The results of the study show that the names associated with sentimentality, patriotism, and family influence the choice of dishes since they generate positive feelings of consumers. Each of these dishes has its own spiritual meaning in the heads of consumers and it attributes particular flavor to the dish (Žaper, 2004). However, it is very important to mention that the given names of dishes can invoke greater expectations that can lead to disappointment in the case they are not met (Richardson et al., 1994). The menu that is noticed as the least appealing is the classical menu with the average value of 2.00 and only $11 \%$ of participants have marked this menu as the most appealing. Generally speaking, the trends of restaurants' offer have been changed and the results of the study were expected. The classical menu is the least convenient to the guests and it is confirmed by recent studies on the changing needs of consumers (Tešanović, 2012, p. $61)$. On the other hand, devastating data can be noticed in Vojvodina's restaurants with only $3 \%$ of special offer (Kalenjuk et al., 2016), which applies to a very important segment of business (Gaste et al., 2015).

\section{CONCLUSION}

On the basis of the research on the impact of names of dishes in the menu on the guest's choice of restaurant food, the following conclusions could be drawn:

- The menus that had words denoting memory of family, authenticity, national characteristics, organic/healthy safe in the names of dishes were more attractive to the guests in relation to the offer based on the dishes with classic names.

- The most desirable foods were those that had in front of their name attribute ecological and healthy safe, then the guests valued dishes with sentimental names and then those with prefix "national" while the same dishes with classic titles were in the last choice.

- This study confirms that when creating the menu one of the important issues to be addressed are the names of dishes. To ensure that this potential is fully used, it is critical to make the analysis of user demand. After that, during the formation of the offer, it is recommended to use the descriptive terminology that will be understood by the guest. The studies have shown that the effect of giving attractive names to dishes is the long lasting one, not transient on (Wansink et al., 2012).

- In addition to the attractive and authentic offer that restaurant places on the market by providing authentic, national and sentimental names to the dishes it also influences the preservation and promotion of gastronomic culture and traditions of the region.

- The research results can contribute to better restaurant practice; if greater attention was paid to the present topic, that would have direct impact on all segments of the restaurant business.

\section{Acknowledgment}

This work is part of the research projects: III-46009 and 46005 funded by the Ministry of Science and Technological Development of the Republic of Serbia.

\section{REFERENCES}

Baourakis, G. (2004). Marketing trends for organic food in the 21st Century. River Edge, NJ: World Scientific.

Cardello, A., Mallero, O., Masor, H., Dubose, C., \& Edelmenan, B. (1985). Role of Consumer Expectancies in the Acceptance of Novel Foods. Journal of food science, 50(6), 1707-1714. doi:10.1111/j.1365-2621.1985. tb10571.

Doyle, D., Connor, M., Reynolds, A., \& Bottomley, D. (1999). The robustness of the asymmetrically dominated effect: Buying frames, phantom alternatives, and in-store purchases. Psychology and Marketing, 16(3), 225-243. doi:10.1002/(SICI)1520-6793(199905)16:3<225::AIDMAR3 $>3.0 . C O ; 2-\mathrm{X}$

Gagić, S. (2014). Osnove ugostiteljstva. Novi Sad: Alfa-Graf. Gase, L.N., Kaur, M., Dunning, L., Montes, C., \& Kuo, T. (2015). What menu changes do restaurants make after joining a voluntary restaurant recognition program? Appetite, 8, 131-135. doi:10.1016/j.appet.2015.01.026

Jones, P., \& Mifli, M. (2001). Menu development and analysis in UK restaurant chains. Tourism and Hospitality Research, 3(1), 61-71. doi:10.1177/146735840100300105

Kalenjuk, B., Tešanović, D., Banjac, M., Gagić, S., \& Radivojević, G. (2016). Offer structure and design of the menu in hospitality industry. Tourism \& Hospitality Industry 2016, Congress Proceedings, (pp. 131-143). Retrieved September 6, 2016 from http://www.fthm.uniri.hr/files/Kongresi/THI/Papers/2016/THI_April2016_131to143.pdf 
Lane, C. (2013). Taste makers in the "fine-dining" restaurant industry: The attribution of aesthetic and economic value by gastronomic guides. Poetcis, 41(4), 342-365.

Ledikwe, J., Blanck, H., Kettel Khan, L., Serdula, M., Seymour, J., \& Tohill, B.R. (2005). Dietary energy density determined by eight calculation methods in a nationally representative United State population. The Journal of Nutritional, 135(2), 273-278.

Lessa, K., Zulueta, A., Esteve, M., \& Frigola, A. (2013). Study of consumer perception of healthy menus at restaurants. Food Quality and Preference, 22(3), 37-46. doi:10.1016/j.foodqual.2016.05.007.

Lončar, D. \& Lončar, M. (2004). Analiza i dizajn jelovnika (menija) kao važan faktor unapređenja prodaje ugostiteljskog objekta. Turizam, 8, 107-109.

Lorenzini, B. (1992). Menus that sell by design. Restaurants and Institutions, 102(7), 106-112.

Mermet, G. (2010). Francoscopie. Paris: Larousse Editions.

Morrison, P. (1996). Menu Engineering in Upscale Restaurants. International Journal of Contemporary Hospitality Management, 8(4), 17-24.

O’Kane, G. (2016). A moveable feast: Contemporary relational food cultures emerging from local food networks. Appetite, 105, 218-231. doi:10.1016/j.appet.2016.05.010

Ozdemir, B., \& Caliskan, O. (2014). Review Article: A review of literature on restaurant menus: Specifying the managerial issues. International Journal Of Gastronomy And Food Science, 22(6), 23-13.

Richardson, P., Dick, A., \& Jain, A. (1994). Extrinsic and intrinsic cue effects on perceptions of store brand quality. Journal of Marketing, 58(4), 28-36. doi:10.2307/1251914
Roseboro, K. (2016). Certified! Fast growing non-GMO, organic, and fair trade trends create big opportunities. Retrieved September 6, 2016 from http://digital.bnpmedia.com/article/Certified!/2502574/308292/article.html.

Sheehy, T. (2015). Traditional food patterns are associated with better diet quality and improved dietary adequacy in Aboriginal peoples in the Northwest Territories, Canada. Journal Of Human Nutrition And Dietetics, 28(3), 262-271.doi:10.1111/jhn.12243:

Tešanović, D. (2011). Osnove gastronomije za menadžere. Novi Sad: Prirodno matematički fakultet.

Wasnik, B., \& Park, S. (2002). Sensory suggestiveness and labeling: do soy labels bias taste? Journal of sensory studies, 17(5), 483-491. doi:10.1111/j.1745-459X.2002. tb00360.x.

Wansink, B., Cheney, M., \& Chan, N. (2003). Exploring comfort food preferences across age and gender. Physiology \& Behavior, 79(4-5), 739-747.

Wansink, B., Painter, J., \& Ittersum, K. (2001). Descriptive menu labels' effect on sales. Cornell Hospitality Quarterl, 42(6), 68-72. doi:10.1177/0010880401426008.

Wansink, B., Ittersum, K., \& Painter, J. (2004). How diet and health labels Influence taste and satiation. Journal of food sience, 69(9), 340-346. doi:10.1111/j.1365-2621.2004.tb09946.x

Žaper, A. (2004). Culinary art - part of culture of life and spiritual heritage in Croatian tourist supply. Naše more: znanstveno-stručni časopis za more i pomorstvo, 51(5-6), 227-238.. 